\title{
Obstetric violence and human development: knowledge, power and agency in Colombian women's birth stories
}

\author{
Violência obstétrica e desenvolvimento humano: saberes, poder e agência em narrativas de \\ mulheres colombianas sobre o parto
}

\author{
Laura Tolton ${ }^{1}$ \\ Marcos Claudio Signorelli ${ }^{2}$
}

\begin{abstract}
Obstetric violence was first described in Latin America, consisting of violence perpetrated mainly by health workers against women during pregnancy, birth or postpartum. It affects women worldwide and represents a challenge for human development, as it negatively affects women's health and rights. This study reflects on the experiences of obstetric violence of a group of Colombian women, bringing visibility to their experiences and analyzing the language they use as a way to understand the issues underpinning these narratives. We adopted qualitative research with in-depth interviews and analyzed the narratives using discourse analysis. This research highlighted: 1) the women's point of view; despite not being aware of the term "obstetric violence," their experiences fit into this category that is often naturalized; 2) a hierarchy of knowledge with the biomedical model as authoritative, in which health professionals do not give adequate weight to women's experiences or knowledge; 3) the relations between obstetric violence and human development, considering women's (dis)empowerment and the limitations that these abuses imply for women's freedom and agency.
\end{abstract}

Keywords: Obstetric violence, human development, birth, violence against women.

\section{Resumo}

A violência obstétrica foi primeiramente descrita na América Latina, consistindo na violência perpetrada principalmente por profissionais da saúde contra mulheres durante a gestação, nascimento ou pós-parto. Afeta mulheres no mundo todo e representa um desafio para o desenvolvimento humano, pois afeta negativamente a saúde e os direitos das mulheres. Este estudo refletiu sobre as experiências de violência obstétrica de um grupo de mulheres colombianas, trazendo visibilidade às suas experiências e analisando a linguagem que elas utilizam como um modo de compreender as questões subjacentes às suas narrativas. Adotou-se pesquisa qualitativa com entrevistas em profundidade, analisando-se as narrativas por meio do método de análise do discurso. Esta pesquisa destacou: 1) o ponto de vista das mulheres, que apesar de não conscientes do termo "violência obstétrica", suas experiências cabem nessa categoria, que é frequentemente naturalizada; 2) uma hierarquia de saberes, com o modelo biomédico sendo autoritário, no qual profissionais de saúde não dão importância adequada às experiências das mulheres ou seus saberes; 3) relações entre violência obstétrica e desenvolvimento humano, considerando o (des)empoderamento das mulheres e as limitações que esses abusos implicam para a liberdade e agência das mulheres. Palavras-chave: Violência obstétrica, desenvolvimento humano, parto, violência contra a mulher.

\footnotetext{
${ }^{1}$ Department of Languages and Linguistics/Institute of Latin American Studies - La Trobe University, Melbourne, Australia. E-mail: L.Tolton@latrobe.edu.au

${ }^{2}$ Department of Collective Health, Federal University of Paraná. E-mail: signorelli.marcos@gmail.com
} 


\section{Introduction}

In 2015 the United Nations launched the Sustainable Development Goals (SDG) as part of the 2030 Agenda for Sustainable Development (UN, 2015). This Agenda is a plan of action for people, planet and prosperity, seeking to eradicate poverty and strengthen universal peace in larger freedom. It includes 169 targets which seek to realize the human rights of all and to achieve gender equality and the empowerment of all women and girls, ensuring that all human beings can fulfil their potential in dignity and equality and in a healthy environment. The SDG intend to build just and inclusive societies which are free from fear and violence. In summary, there can be no sustainable development without peace and no peace without sustainable development.

Improving the lives of women and girls is a crucial target in the SDG, since gender inequality remains a key challenge. The achievement of full human potential and sustainable development is not possible if one half of humanity continues to be denied their full human rights and opportunities. The World Health Organization (WHO) estimates that globally one in three women are victims of violence (WHO, 2013). This violence is perpetrated mainly inside homes, the places that are supposed to be the safest for women, and by a family member or a known person (SAFFIOTI, 2001). This highlights the size of the challenge women face.

However, violence against women does not only happen inside homes or with strangers in the streets. It can occur in places like health services, perpetrated by those who are supposed to care for women, like health professionals. It can also occur in all the cycles of women's lives, from infancy to old age, particularly in the phases of more vulnerability. This paper focuses on one specific type of violence against women, which is the violence practiced by health professionals during the period of pregnancy, birth and post-partum. The term "obstetric violence," used to describe this, has recently gained recognition in the research world. Some studies and public policies may refer to the problem as "violence during childbirth" (WHO, 2015) or "mistreatment during childbirth" (SAVAGE; CASTRO, 2017), while other studies adopt the term "institutional violence in maternity units" (or maternity hospitals) (AGUIAR et al., 2013; AGUIAR; D'OLIVEIRA, 2011) and yet others refer to 
"mistreatment and abuse in maternity care" (BOHREN et al., 2015). In this study we adopted the term obstetric violence, as it is the most commonly used across the Latin American region.

The concept of obstetric violence has only recently become internationally known through years of use by Latin American birth activists. Brazil pioneered discussions of respect in childbirth, first in 1993 with the foundation of ReHuNA ("Rede pela Humanização do Parto e do Nascimento"/The Network for the Humanization of Labor and Birth) and then in 2000, with the First International Conference for the Humanization of Birth. RELACAHUPAN ("Red Latinoamericana y del Caribe para la Humanización del Parto y el Nacimiento"/The Latin American and Caribbean Network for the Humanization of Childbirth) came out of the second meeting, leading the conversation about respected childbirth in the larger region (SADLER et al., 2016). Venezuela became the first country to define obstetric violence in law in the following way in 2007:

The appropriation of women's bodies and reproductive processes by health personnel, which is expressed through dehumanizing treatment [and] abuse of the medicalization and pathologization of natural processes, resulting in women losing autonomy and the ability to decide freely about their bodies and sexuality, which negatively impacts their quality of life (VENEZUELA, 2007, p.8).

This law provides examples including "inattention to obstetric emergencies, birth in the lithotomy position, needless separation of mother and child, and augmentation of labour or caesarean delivery without consent" (DIAZ-TELLO, 2016, pp.61-62). Today, Mexican, Argentinian and Venezuelan laws characterize obstetric violence as part of violence against women. Through the broad ideas of abuse of medicalization and pathologization of natural processes, these laws address unnecessary medical interventions, such as routine episiotomies, unnecessary caesareans and many others.

Although obstetric abuse was first named in Latin America, it is a global issue (SAVAGE; CASTRO, 2017), and the spectrum it can include is broad. A systematic review of the mistreatment of women during childbirth (BOHREN et al., 2015) presented a number of themes constructed from qualitative evidence synthesis, which we summarize here. Physical abuse included beatings, hitting, slapping, the use of extreme force, pinching, and kicking, as well as restraints and gags. Verbal abuse was reported across all regions and country income levels. This included rude language, judgmental and accusatory comments, threats of poor outcomes and withholding treatment, ridicule, scolding, and blame for poor outcomes. Stigma and discrimination occurred in relation to four broad categories: ethnicity/race/religion, age, socioeconomic status and medical conditions. Often 
professional standards of care intended to address the basic needs of women during childbirth were not met. These included: lack of informed consent and confidentiality, improper conduct of physical examinations and medical procedures, and neglect and abandonment. In the category of poor rapport, women described staff as disrespectful, unwelcoming, misbehaving, having negative attitudes, and being unsupportive, judgmental, unfriendly, unhelpful, rude, impolite, sarcastic, discouraging, unprofessional and unkind. Three broad categories in this theme were ineffective communication, lack of supportive care and loss of autonomy. Women also reported health system conditions and constraints including lack of resources, lack of policies, and facility culture which contributed to the problems of mistreatment.

Considering this complex panorama, this paper reflects on the experiences of obstetric violence of a group of Colombian women. We bring visibility to their experiences and analyze the language they use as a way to understand issues that underpin the women's narratives. We also have attempted to establish a dialogue between this issue and human development, focusing on women's freedom, empowerment and agency.

\section{Methodology}

This study is based on a qualitative approach and takes places within the framework of feminist critical discourse analysis. Discourse analysis aims to make visible aspects of social life that are taken for granted by analyzing the use of language (CAMERON, 2001). Feminist critical discourse analysis in particular highlights the fact that language reflects and challenges gendered power asymmetries. In this way, feminist critical discourse analysis exists as a sort of analytical activism with feminist social justice as its goal (LAZAR, 2007). This study aimed to collect women's narratives about their own birth experiences and to analyze gender and power-related aspects which appeared in their stories. Data was gathered through in-depth interviews (LIAMPUTTONG; EZZY, 2005) that were recorded, transcribed and analyzed using discourse analysis.

The first author, Tolton, interviewed ordinary Colombian women who have given birth, using the snowball technique (LIAMPUTTONG; EZZY, 2005) to find participants. These participants included 15 mothers between the ages of 30 and 65 who were interviewed in Bogotá, Colombia in June and July 2012 and November and December 2013. The questions were loosely based on 
questions used by Davis-Floyd (2003) in her interviews about birth. Tolton's intent was to develop an understanding of how women understood and described their own birth experiences.

All participants were adults and freely consented to participate in this research. Ethical clearance was obtained from the University of Canberra and the Australian National Statement on Ethical Conduct in Human Research (NHMRC, 2007) guidelines were followed in this research. Although most of these women with had some experiences which they found at the very least unpleasant or uncomfortable, they all appreciated having the opportunity to tell their birth stories. When Tolton thanked women for allowing her to interview them, they consistently showed gratitude and often pleasure for the opportunity to share and reflect on their experiences. Names and references have been de-identified for anonymity and confidentiality. Tolton translated the excerpts from the women's narratives given here into English.

\section{The (in)visibility of obstetric violence}

Research from a midwifery and feminist standpoint has described and criticized medical understandings of pregnancy and birth and the ways that these contribute to the disempowerment of women. However, very little of this research has been from a discourse analytic perspective, and few studies have examined how women who have experienced obstetric violence characterize it (REGIS, 2016). The present study analyzes mothers' ways of describing obstetric violence as well as resistance through their portrayals of agents and actions in birth.

When analyzing these interviews for the present article, we first read through them looking for experiences of obstetric violence, defining this for practical reasons as when women made it clear that they were upset because of actions or inaction of medical personnel which might fit into the category of obstetric violence as described above. Considering excerpts which had some importance for the women provided a reasonable amount of description, rather than elicited shorter responses related more directly to questions. Also, using excerpts which were meaningful to the women allowed us to find examples which likely would include women's own portrayals of power struggles, ideal for a critical discourse analytic study, as opposed to simply a more sociological tally of things such as inductions or being made to stay on their backs.

It would have been possible to find many more examples if we had defined obstetric violence as Venezuelan law does or using elements commonly understood as part of obstetric violence. All of 
the interviews included at least several examples of obstetric violence defined those ways. However, women's descriptions were uninteresting to our study in areas of the interviews where the women did not see anything wrong with how they were treated.

On the other hand, if we had examined these interviews for what the women themselves defined explicitly as "obstetric violence," then we would have had no examples to analyze. None of the women Tolton interviewed used the words "obstetric violence" to describe their experiences. Women who are involved in birth activism might be likely to use the words "obstetric violence," but not women who experienced birth 10-20 years ago, nor even women in general nowadays. The women interviewed each had personal ways of understanding their experiences, and many of them found certain aspects uncomfortable, unpleasant, or even very angering. They have verbally 'written' their stories in these interviews to frame their overall experiences in ways that are strong and positive for them. More generally, many women who have had experiences that fit a definition of violence do not classify them as violent, because this can affect their self-perception in terms of agency and victimhood, as well as strength and weakness. This is a pattern common in other forms of violence against women, such as intimate partner violence (SONEGO et al., 2013). It is frequent for women not to name these circumstances as violence or not to consider themselves victims of violence (SONEGO et al., 2013), because violence against women is normalized in most societies. Interestingly, "obstetric violence [is] one of the most invisible and naturalized forms of violence against women" (SADLER, 2016, p.50). The dominant ideology asserts that it is normal for birth to be horrific and, correspondingly, "the bad feelings are just part of birth" (BRUJIN; GOULD, 2016, p.45).

For these reasons, when deciding which excerpts of stories to analyze, we considered the women's experiences based on their own perceptions rather than based on whether they used the words "obstetric violence," “disrespect" or "mistreatment." We analyzed these sections of the interviews using discourse analysis and asking certain questions as we examined the data: where was different people's knowledge present and exerting force? How did these women name and describe actors and actions? As knowledge and power are key to our understanding of obstetric violence, these were key in the data analysis. This paper presents excerpts from three interviews.

\section{A hierarchy of knowledge between health professionals and women}


In the following story, a woman we have called Luciana ${ }^{3}$ presents the first vaginal exam she had during pregnancy using the characteristics of a rape story. These events set the scene for the negligence she experiences during labor which leads to a near death experience as well as the possibility of her son dying. This story also exemplifies the hierarchy of knowledge between health professionals and women.

De ese tacto, que fue al comienzo del embarazo, que todavía no sabíamos sino Enrique y yo... El médico me examinó y todo eso y no sé qué; y luego me dijo pues que me subiera en la camilla y me quitara los cucos y todo eso y entonces me hizo el tacto, que fue el primer tacto de mi vida, que fue lo peor, o sea lo peor fue eso, el que me hubiera metido los dedos, el que me hubiera visto ese doctor, el que todo eso porque ahí fue donde otra persona diferente a Henry, o sea me había como violado esa intimidad mía sí... esa persona, yo me sentía violada, maltratada. Uy sentía pero horrible, mejor dicho, sentía rabia, sentía...

That vaginal exam, that was at the beginning of the pregnancy, when only Enrique and I knew about it...The doctor examined me and all that and whatever; and then he told me to get up on the bed and take my underwear off and all that and then he did the vaginal exam, which was the first vaginal exam in my life, and it was the worst, I mean the worst was that, that he had stuck his fingers into me, that that doctor had seen me, that all of that because that was when a person other than Henry [nickname for husband], I mean, had violated that intimacy of mine... that person, I felt violated, abused. Oh, it felt horrible, really, I felt angry, I felt...

Luciana sets up her story by marking the innocence and newness of her young family: only she and her partner knew she was pregnant. Here, the actions all belong to the doctor; Luciana has nearly no agency in this part of the story. "El médico me examinó," she says, referring to a general physical exam. Then the doctor gives her orders. "Me dijo" (he told me) "que me subiera en la camilla y me quitara los cucos" (to get up on the bed and take my underwear off). She uses the subjunctive (in bold), showing that he was telling her what to do, not requesting. The only agency that Luciana has in this excerpt is at the end, where she says what she feels.

Luciana refers to her innocence again by saying that this was the first tacto (vaginal exam) of her life. She shows her evaluation of what happened through repetition of the words "lo peor" (the worst thing). In this part of the story, Luciana brings in that something was not right in the doctor's actions through the references to that he was not her partner and that he violated her intimacy, and as a result she felt raped and abused. She constructs the violence by naming the man who put his fingers into her as "otra persona diferente a Henry," someone other than her partner. Her partner has

\footnotetext{
${ }^{3}$ All names of women interviewed and the people they mention have been changed to pseudonyms.
} 
permission to touch her; whereas when this other man does it, it constitutes a violation. She first hedges the statement "violado esa intimidad mía" (violated that intimacy of mine) by saying "como" (sort of), but then strengthens it by referring to her feelings as those of having been "violated, abused." The word "violar" in Spanish can be translated as 'violate' or 'rape'.

Later in the interview, Luciana tells the story of when she was in labor and she refused more tactos. In response, the doctor said "pues mija, friéguese sola" (well, my dear, then you can fuck up all alone) and left her alone all night, until a doctor found her in the morning and she was nearly dead. It was at that point that the doctor explained to her husband, who was waiting outside, that probably only she or the baby would survive.

[Hacía fuerza] para que no me doliera más y porque ya no quería más tactos y todo eso. Entonces el último médico que vino, cuando yo le dije que no quería más tactos y no me dejé hacer tacto, entonces el médico me dijo "pues, mija, friéguese sola", y efectivamente me dejaron sola. Entonces yo sé que llevaba muchas horas y sé que ya había pasado toda la noche, llegó un momento en que yo estaba como cansada y yo tooodo el tiempo movía la cabeza y me mordía los labios de abajo...Nadie me miraba ni nada, nadie nada. Yo no sé, yo crei que me iba a morir... porque hubo un momento que yo sabía ... yo sabía, que era, yo sé yo supe que era de día porque decían "buenos días", cuando toda la gente llegó y comenzó "buenos días, buenos días"...En un momento de lo que yo sentía los dolores y todo... yo comencé a ver blanco, blanco, blanco, blanco, blanco brillante... era muy blanco y muy brillante, como un túnel, era blanco, blanco y brillante... Como si uno se fuera yendo lejos, lejos, lejos, lejos, lejos y alcancé a oír a un médico que le preguntó a una enfermera "¿esa señora desde cuándo está ahí?" La enfermera le dijo "doctor, desde ayer por la tarde", entonces el doctor sí me empezó como a examinar... y le dijo a la enfermera, "esta señora está muy mal, hay que hacerle una cesárea rápido...la dejaron mucho tiempo..." Y yo sentí que me empezaron a poner como, como un gorro...

[I pushed] so that I wouldn't feel more pain and because I didn't want any more vaginal exams and all that. Then the last doctor who came, when I told him I didn't want any more vaginal exams and I didn't let one be done to me, so then the doctor said to me "well, sweetie, then you can just get fucked alone," and effectively they left me alone. Then I know that I had spent many hours and the whole night had passed, a moment came when I was like tired and aaall the time I moved my head and bit my bottom lip... No one looked at me or anything, no one, nothing. I don't know, I thought I was going to die... because at one point I knew...I knew that it was, I know I knew that it was daytime because everyone said "good morning," everyone started saying "good morning, good morning," when everyone arrived and began "good morning, good morning"... At one point when I was feeling the pains and all... I started to see white, white, white, white, white shining... it was really white and really shiny, like a tunnel, it was white, white and shiny... Like if you're going far, far, far, far, far away and I was able to just hear the doctor who asked a nurse "how long has this lady been there?" The nurse told him "doctor, since yesterday afternoon," so then the doctor did actually start to like examine me... and he said to the nurse, "this woman is doing really bad, a caesarean has to be done 
quickly...they left her a long time..." And I felt that they began to put like, like a cap on me...

The mother's personal knowledge is present in two parts of this section of the story. The first time is in her recognition that the vaginal exams that she was experiencing were a violation and that she could refuse them. Here, Luciana portrays herself as taking control, as evidenced in the repeated explicit use of "yo" (I) and also the use of the yo-form of verbs, showing her agency. In Spanish it is common to drop the subject of a sentence when the subject is "yo," but in this section of the story the speaker uses "yo" several times. Most notably, we can see this when she tells about taking control over her situation: “yo le dije que no quería más tactos y no me dejé hacer tacto" (I told him I didn’t want any more vaginal exams and I didn't let one be done to me), giving herself the action in this sentence as well as in several others.

In this interaction, Luciana exerts control over her body based on her own physical knowing, and then the medical personnel react by punishing her for resisting their customary exams. They enforce the hierarchy of power and knowledge through their actions. When she refuses their vaginal exams, prioritizing her knowledge of her physical needs over theirs, in reaction they refuse to monitor how she is doing until the next day, when a new doctor begins his shift. Effectively, the mother is left to "fregarse" (get fucked, be screwed), and she describes herself as nearing death when the next doctor finds her.

This interaction involving knowledge and power may be a typical example of obstetric violence. Sonia Monroy (2017) tells a similar story at the beginning of her thesis "El continuo ginecobs-tétrico: experiencias de violencia vividas por mujeres gestantes en servicios de salud en Bogotá." In the story of when Monroy herself was born, the doctor abandons Monroy's mother "como represalia por reclamar a una enfermera por hurgar sus genitales con las uñas largas y sin guantes" (abandonment as retaliation for complaining about a nurse digging in her genitals with long nails and without gloves; MONROY MUNOZZ, 2012, p.13), and then both the baby (Monroy herself) and her mother almost die as a result of being left alone. An Australian study about what happens when women refuse recommended medical care found that "both midwives and doctors abandoned women as a kind of punishment" (JENKINSON et al., 2017, p.6). The pattern in these interactions fits quite easily into the pattern of how violence against women more generally works. The victim transgresses the boundaries of what is expected of her, and in response, the aggressor, in this case the 
medical personnel, punish her as a way to put her back in her place, to teach her to abide by society's rules (TOLTON, 2010).

The second time the mother's knowledge is evident in this story is when she experiences her own nearness with death. She uses a series of negatives to show the beginning of leaving this world: "nadie me miraba ni nada, nadie nada" (no one looked at me or anything, no one, nothing). People were interacting around her, greeting one another, but no one directed their words nor their gaze to her. Symbolically she represents that she was leaving social life, beginning the journey toward death. Then, using "yo" (I) repeatedly again, she says "En un momento de lo que yo sentía los dolores y todo... yo comencé a ver blanco, blanco, blanco, blanco, blanco brillante... era muy blanco y muy brillante, como un túnel" (At one point when I was feeling the pains and all... I started to see white, white, white, white, white shining... it was really white and really shiny, like a tunnel) voicing here a commonly expressed vision of a near death experience. At this point, her knowledge concurs with the doctor's knowledge, as the doctor speaks with Luciana's husband, telling him that they will only be able to save the baby or the mother. As the mother's and the medical knowledge are in alignment, there is no struggle. The doctor is now able to save the woman from the situation that it seems medical customs for giving birth (Luciana being on her back, unable to move around) and the doctor from the previous shift placed her in. A doctor recognizes this, telling a nurse "esta señora está muy mal, hay que hacerle una cesárea rápido...la dejaron mucho tiempo," (this woman is doing really bad, a caesarean has to be done quickly...they left her a long time) giving responsibility to the medical personnel who left her alone and also bringing up the medical belief that in birth things must happen according to a time schedule. Through this relatively manufactured situation, medicine is able to demonstrate its power in a heroic role.

This situation exemplifies what some authors describe as the "biomedical paradigm" or "biomedical model" (CAMARGO JÚNIOR, 1997; 2003). This social construct consists of the way that life can be reduced to a medical condition, the human body is viewed as a machine, and pregnancy is understood as a disease that requires hospitals, medical procedures and drugs. This approach is based on the medicalization of life, and it can underpin the issue of obstetric violence, since only medical knowledge is taken into consideration. Patients' and popular or traditional knowledge are devalued, a clearly hierarchical approach. In such experiences, the biomedical paradigm functions as a mechanism or knowledge structure that monitors, controls and punishes women who do not accept these norms. Additionally, Barros (2002) argues that the management of pregnancy and childbirth as if they were a disease, which then requires permanent medical attention, is a good example of 
something physiological that is 'medicalized'. To confirm this assertion, the author highlights rising caesarean rates which do not have adequate technical justification and the systematic monitoring of pregnancy by ultrasonography, even in pregnant women with no previous or current history that might be considered a "risk."

Obstetric violence can be explained as struggles between levels in a hierarchy of knowledge, that is, "a way of organizing power relations in [the birthing] room which makes them seem literally unthinkable in any other way" (RAPP in JORDAN, 1997, p.55). A consequence of such a hierarchy is that knowledge seen as authoritative is legitimated in discourse and actions, and other kinds of knowledge are devalued or even dismissed (JORDAN, 1997). In the birthing room as in prenatal and postnatal medical consultations, medical knowledge is considered authoritative. Doctors' knowledge ranks highest on this scale, clearly being considered authoritative, and after that comes nurses' knowledge. Women's knowledge in birth, which comes from knowing and experiencing one's own body, is generally undervalued and its existence often ignored (BAKER et al., 2005; JORDAN, 1997). Usually traditional knowledge is not even acknowledged.

Struggles between these levels of knowledge often play out when there are contradictions between the mother's understanding and that of the medical team. If she does not fit the medical staff's expectations, perhaps by asserting her own knowledge through words or actions, there exists "the possibility of powerful sanctions ranging from exclusions from the social group to physical coerciveness (JORDAN and IRWIN, 1989)" (JORDAN, 1997, p.57). Violence against women is commonly enacted as part of teaching women to stay in their place (TOLTON, 2010), without regard to whether women are asserting their own knowledge. Obstetric violence follows this pattern, as "the disciplining of women and their bodies is most evident in relation to childbirth" (BAKER et al., 2005, p.334).

\section{Obstetric violence and human development: women's freedom and agency}

Another illustrative case comes from a Colombian woman whom we will call Mariana. Her story is useful to reflect on the notions of human development, freedom and agency, as proposed by Amartya Sen (2000), which we will further discuss. Mariana indicates the knowledge of what it is like to push a baby out as an important factor differentiating the stories of the two times she has given 
birth. In the first birth, the medical personnel tell her that they are going to give her oxygen, and then they put a mask on her, which is actually to put her to sleep. She describes when she woke up: "Lo primero pensé fue 'ya nació, pero ¿cómo?' Yo no supe qué fue pujar; no supe nada, nada; ya nació" (The first thing I thought was "he was born, but how?" I didn't get to know what it's like to push; I didn't experience anything at all; he was already born).

The word "supe," which she uses, is a form of the verb "saber," to know. Using this verb, this mother equates experience with knowledge. She was unconscious, and so she says "no supe" meaning that she didn't get to know, that is, to have the bodily experience, of certain things. She says "no supe qué fue pujar" (I didn't get to know what it's like to push) to emphasize the element of pushing in particular as what she wanted or expected to experience. Then, "no supe nada, nada" (I didn't experience [know] anything at all) shows that not only did she not get to push, she didn't get to really experience giving birth at all. This mother wanted to have knowledge of the baby's birth, to experience pushing, and in her first birth she was denied this through being given anesthesia by surprise, without consent. Lupton and Schmied (2013) discuss how difficult it can be for women who receive anesthesia for caesareans to reconcile their bodily status from pregnant to non-pregnant and to understand that their babies have been born.

Their bodies are experienced as absent from the birth because they are numbed or
unconscious at the pivotal moment of the infant's body emerging and cannot even
view the process. As they cannot rely on their bodies' sensations, the physical
experience must be interpreted by others at the time or after the event once the
woman has regained consciousness (LUPTON; SCHMIED, 2013, p.835).

According to Mariana's own evaluations, the emotional and physical outcomes of the two births were very different. Describing the first birth, she explains "al niño lo ayudaron a sacar con espátulas...entonces el maltrato fue...terrible" (the child was taken out using spatulas...so the damage was...horrible). She contrasts it briefly with the second: "con César fue muy bonito; fue súper" (with César it was beautiful; it was super), then she returns to talking about the first. She tells about the use of forceps, bad tearing, and being unconscious, repeatedly evaluating this experience and the damage to her body with the adjectives "terrible" and "horroroso" (horrific).

She describes the first birth experience as "más clínica" (more hospital-like) and the second as "súper," "como si hubiera nacido aquí en la casa" (super; as if he had been born here at home). This differentiation is also carried out through agency in each of the stories. Although the verb use 
portrays nearly all actions as being carried out by medical personnel in both births, the object pronouns show a clear difference. In the first birth the actions were nearly all done to the mother (as shown in the use of the word me), and at the end, to her baby (al niño lo). The use of the term "más clínica" also clearly reinforces the hierarchical biomedical approach, discussed in the previous section.

In the story of the second birth, the medical personnel carry out most of the actions; however, they are not described as doing so many things to the mother. This seems to be because the baby was already crowning when she arrived at the hospital; this excerpt begins with the nurse's words, " $\mathrm{Ya}$ está aquí, ya está aquí, ya está naciendo; corra a la sala de partos." ([the baby]'s here right now, [the baby]'s here right now]; and rush! to the delivery room). The object pronoun " $m e$ " is used only twice: when the mother's legs are placed in stirrups "ella colocándome la pierna," and when the doctor tells her to push: "el doctor me dijo en la próxima contracción 'puje, puje." In fact, although the doctor telling her to push is an order, this sentence also describes an action that the mother herself carries out, the same action that she wanted to experience in the first birth.

The application of general anesthetic together with deception of the mother was a clear example of restriction of women's freedom. Mariana did not have freedom to participate in one of the most important moments of her life: the birth of her children. She had such a strong feeling of not having participated in the birth that she in fact believed that the birth did not happen. This freedom is extremely significant to human development. Freedom is one of the ways to achieve development, according to Amartya Sen (2000). For this author, development can be seen as a process of expanding the real freedoms that people need to do as they wish in their lives. Focusing on human freedoms contrasts with narrower views of development, such as associating development with the growth of gross national product, with increase in income, industrialization, or with technological advancement. Income growth can be very important as a means to expand the freedoms enjoyed by the members of a society, but freedoms also depend on other determinants, such as social arrangements, like adequate health care and human rights. For Sen (2000), development requires the removal of major sources of what he terms "unfreedom," such as poverty, violence, and intolerance. Instead of freedom, these women were silenced and even worse, in this specific case Mariana was put under general anaesthesia unknowingly, not being able to be an active agent of her own baby's delivery. When women do not have freedom to be "agents" in childbirth, human development is impeded.

For Sen (2000), the development of a society is evaluated primarily by the substantive freedoms that the members of that society enjoy. Having greater freedom to do the things one has 
reason to value is (1) significant in itself for the person's overall freedom, and (2) important in fostering the person's opportunity to have valuable outcomes. Sen (2000) also argues that capabilities are central for development: the expansion of people's "capabilities" to lead the kind of lives they value and have reason to value. Therefore, when Colombian women's rights to experience their babies' births are denied, their capabilities are restricted, consequently restricting their freedom and human development.

Mariana felt strongly about being denied the bodily knowledge of pushing and giving birth. When they put her under general anesthetic, there was no consent, and it also took away her possibility of having the embodied experience, restricting her freedom to experience giving birth and taking away her capability to be an agent. Lupton \& Schmied (2013) suggest that this sort of sense of disembodiment can lead to disappointment, guilt, anger and frustration. "Health professionals and attendants working with women in labour and childbirth need to allow not only for the physical and emotional but also the ontological dimensions of how a woman experiences both her own body and that of the body-being-born" (LUPTON; SCHMIED, 2013, p.839).

\section{From babies to monsters: when discourses produce obstetric violence}

One of the key points that this research found is that obstetric violence is produced through health professionals' discourses. Verbal violence seems to play a significant role in obstetric violence, since many women refer to words and phrases professionals used that directly attacked them and affected their emotional state. A third interviewee, whom we will call Tatiana, presents a story with an example of a health professional's discourses permeated by verbal violence:

Cuando me hicieron la ecografía tres días antes, el médico, un médico grotesco, eso sí no me gustó, ese médico que me hizo la ecografía. Eso fue un miércoles y Carolina nació el sábado y me acuerdo tanto de lo que escribió y todavía la tengo guardada. Me escribió "posibles malformaciones congénitas del feto debido a la obesidad de la paciente". No era obesa sino hinchada, y yo me la imagi-, yo lloraba porque dije "mejor dicho, va a nacer un monstruo"... Y ahí la tengo guardada... Ahi la tengo guardada: "posibles malformaciones congénitas"... y un médico grotesco, grotesco, uy...

When they gave me the ultrasound three days before, the doctor, a hideous doctor, I really didn't like that, that doctor who did the ultrasound. That was a Wednesday and Carolina was born on the Saturday and I remember so much what he wrote and I still have it here. He wrote [for me] "possible congenital deformations of the fetus 
due to the patient's obesity." I wasn't obese but just swollen, and I imagin-, I cried, because I said, "really, it's going to be a monster"... And I have it over there... I have it over there: "possible congenital deformations"... and a hideous, hideous doctor, ugh...

There is an interaction in this story between two different people's knowledge. The doctor's knowledge is represented as having some authority, seen in that the mother still protests against it today as she tells the story. In this situation the doctor's knowledge is suggested not only through being called a "doctor" (rather than an "ultrasound technician"), implying that he has extensive medical training, but also in that he is interpreting an ultrasound. The fact that the mother defends herself to the interviewer nearly thirty years later -- "yo no era obesa sino hinchada" (I wasn't obese but just swollen) -- speaks to the power of the doctor's words over her. At the same time, this mother's defense also indicates that she is implicitly recognizing her own knowledge. The presupposition in this statement is that there wasn't a need for the doctor to write and say these words, because, after all, the mother wasn't obese, and the interviewer and the mother both know (although it is not said in the interview) that her daughter was born perfectly healthy. The mother's knowledge includes her experience of her daughter, who had no deformations when she was born and today is a healthy and successful woman.

Looking back to tell this story, the mother communicates both her strong emotional reaction to this experience and the fact that it can easily still be quite present for her. She calls the doctor "un médico grotesco" (a hideous doctor), showing the strength of her feeling toward him through both repetition of this evaluation and the choice of such a negative adjective. She makes this experience vivid and brings it into the present by recalling the day of the week and citing the exact words on the paper he gave to her, words that scared and worried her. The doctor attributed deformations in the fetus to her size as the mother, laying responsibility on her for this outcome that was only ever a possibility. This fits with the idea that women are required to take personal responsibility for "stringently monitor[ing] and control[ing] their body for the sake of [the health and wellbeing of] their foetuses" (Lupton, 2012, p.330) as well as the problematic assumption that "the 'quality' of the foetus is fully within the control of the pregnant woman" (Lupton, 2012, p.337). The daughter whom she had so wanted, that she was so excited for (as communicated earlier in the interview), was transformed into a monster in her mind with the doctor's words that she repeats: "posibles malformaciones congénitas" (possible congenital deformations). The repetition suggests the impact that she felt from the doctor's words and her wish to communicate that impact to the interviewer. She 
also brings this experience into the present by repeating that she still has the piece of paper, perhaps implying that she could show it to the interviewer.

Verbal abuse can play a significant role in obstetric violence, and it is often accompanied by other forms of violence, as revealed in these stories. To intentionally neglect by leaving women unattended in hospital corridors, to mutilate women's genitals with episiotomies, to touch women's bodies without their consent and to call their babies "monsters" fits into different forms of abuse practiced by health workers during childbirth. With these cases brought forth in this paper it is possible to infer that obstetric violence can be verbal, but also physical, psychological, sexual and through negligence. These circumstances may be not seen by health workers as violence. Perhaps this is because the biomedical model engenders authority to them, creating hierarchies of power and knowledge that somehow "allow" them to produce such acts. However, these acts deeply affected the Colombian women interviewed.

\section{How do women resist obstetric violence? Insights for human development}

At the same time as these narratives aim to bring visibility to the issue of obstetric violence, we also want to highlight that these women are not passive subjects, and in many cases, they do not resign themselves to the abuse practiced against them. Obstetric violence is a delicate issue that occurs at a moment of extreme vulnerability for women. However, we do not want to reinforce stereotypes such as victimization. Many of these women created strategies to resist this abuse, and this is also important to include in the wider discussion of obstetric violence. One such strategy is exemplified in the following story in which a mother uses knowledge to maintain control over what happens to her and her baby.

Catalina was planning a humanized birth, and had been going to parent education sessions held by a humanized birth doctor. She started having contractions at only 29 weeks. That particular day, the humanized birth doctor was not available to attend her, nor was the doctor she was seeing in parallel through her insurance. Instead, she had to see another doctor through her insurance, whom she had never met before.

In this segment of her story, Catalina repeatedly insists on asking for information from both the doctor and the nurse. She asks the doctor why she's having contractions so early, expecting that he will tell her they are Braxton-Hicks (intermittent contractions that some women notice which occur 
throughout pregnancy, commonly believed to strengthen the uterus in preparation for labor) and not actual premature labor, and send her home. Instead, he is "very evasive" and says that he's going to give her a pill to "calm her down." Then, when she asks the nurse what the pill is for, the nurse says "it's to speed up your contractions."

Catalina uses knowledge as a way to maintain control over what happens to herself and her baby. The doctor tries to keep the information from her, through avoiding answering questions (being "evasive") and lying about what the pill will do. He talks down to her, suggesting that she needs to calm down, rather than providing the information she requests which would allow her to participate in the decisions about her care. Not only his lies but also his actions constitute obstetric violence in that it is medically inadvisable and patently unsafe to induce labor at 29 weeks when there is no indication this may be necessary.

Based on the information the nurse gives about the pill, Catalina refuses to take it. In her story, she tells the nurse twice "[esta pastilla] no me la voy a tomar" (this pill, I'm not taking it). Then the doctor returns, "furious," and "rude, extremely rude," insisting that she must take the pill. She tells him:

Le firmo donde diga que yo no me voy a tomar la pastilla pero no me la voy a tomar. Primero porque usted me mintió. Y si usted está mintiendo, me dice a mí una cosa y la enfermera me corrobora que esa pastilla es para..." Entonces yo le decía "No me la voy a tomar. Yo ya no confio en usted. No me puedo poner en manos de usted. No lo voy a hacer". Y yo guardé la pastilla, eh y firmé y le dije "y me voy" y me fui. $Y$ empezaron a bajar las contracciones pero yo le dije a mi pareja "bueno, si vuelve, vamos a otro médico pero yo donde ese señor no voy"... Nos fuimos a la casa y todo se tranquilizó, y estuvimos muy atentos pero eso de que tú sabes que no!... y yo tenía la información que nos había dado Ricardo [médico del parto humanizado] de las falsas contracciones...

I'll sign wherever it says that I won't take the pill, but I'm not taking it. Because you lied to me. And if you're lying, you say one thing to me and the nurse confirms for me that that pill is for..." So I said to him "I'm not taking it. I don't trust you anymore. I can't put myself into your hands. I'm not doing it." And I put the pill away, uh, and I signed and I said "and I'm leaving" and I left. And the contractions started to get weaker but I said to my partner "okay, if this comes back, we'll go to another doctor but I am not coming back to this man"... We went home and everything calmed down, and we were watchful but it was one of those things where you know it's just not right!...and I had the information that Ricardo [humanized birth doctor] had given us about false contractions... 
Catalina effectively refuses what seems to be unsafe medical treatment, strengthening her own authority using the written word and recognizing that she has knowledge from the humanized birth doctor that gives her a way to understand what her body is doing.

This situation exemplifies what Amartya Sen (2000) proposed as "agency," a fundamental component of development. For Sen (2000), development essentially advocates two primary issues: (1) increasing people's freedom and (2) their free status as agents. Therefore, development depends on the freedom that people (agents) have to be able to be and to do all that they are capable of being and doing. This should be according to their own values, which they want to preserve. The cases revealed by these Colombian mothers exemplify how they were not respected as agents, but also highlight at the same time how some of these women were agents of their own stories, able to cope with the situation and even expressing their values, claiming respect from those who underestimated their capabilities.

While women should not be devalued, we also recognize that structural factors need to change to facilitate respectful treatment of women in health care and in society. Individual health professionals experience stressful routines within health facilities, many times with precarious working conditions. Obstetric violence is a "symptom of fractured health systems and locally expressed power dynamics that conspire against both patients and providers" (FREEDMAN; KRUK, 2014, p.e43). We must "confront the often harsh realities at the front line of resource-constrained health systems" not only "by supporting and reinforcing the agency of women and communities to demand better care" but also "empowering health workers and managers to make necessary changes" in order to be able to work toward respect for women in birth (FREEDMAN; KRUK, 2014, p.e43). This should never be an excuse to mistreat patients. Also, these cases should not be generalized to all health professionals nor to the reality of all Colombian mothers. Rather than intending to blame certain professional categories, we argue that these cases promote insights to think of obstetric violence as a relatively common component of the biomedical paradigm that may be present across different countries.

Additionally, we must mention that obstetric violence, as part of violence against women, is not limited to developing countries. In fact, "in many countries, including high-income ones, the best available evidence is not always used to inform maternity care; rather practice is driven by local beliefs about childbirth, and professional or organisational cultures." (SADLER et al., 2016, p.48). This means that developed countries often have unnecessarily high rates of unnecessary interventions, which correspond to obstetric violence. However, research about obstetric violence generally comes 
from and focuses on developing countries, whereas research on a closely related aspect of the problem, emotional birth trauma, is more likely to come from developed countries. At this point, it is necessary to use research from different cultural contexts, as there is insufficient evidence from one region about varied aspects of the problem. In the future, it would be beneficial to explore crosscultural similarities and differences in obstetric violence in disparate contexts in order to best consider strategies for working to eliminate the problem.

Finally, we need to consider the problematic nature of the SDG in relation to obstetric violence. The SDG publicly commend increased access to healthcare facilities and an increase in numbers of health professionals, which theoretically could bring many health improvements for pregnant women. However, assuming that the biomedical model will persist in healthcare settings, and this model may limit women's freedom and their capacity to be agents, this is likely to also increase obstetric violence, which limits development. Considering Amartya Sen's assumptions about development, based on individual freedom, it would be necessary to improve these health services, particularly qualifying health professionals to become aware of obstetric violence and consequently to prevent it in order to achieve development. It is also important to consider women's decisions about where to give birth and which attendants to choose, and the ways that these scenarios could lead to more or less obstetric violence. These issues cannot be neglected; otherwise the SDG is a double-edged sword for women.

\section{Final considerations}

The cases we described in this study represent both challenges and potential for human development. International agencies such as the United Nations and The World Health Organization are launching important policies to promote health and development by reducing violence and inequity and increasing public health coverage. They particularly target the more vulnerable, such as women and children. In recent years, many Latin American countries launched policies targeting intimate partner violence, sexual violence and femicide. However, there are still many gaps in the field of violence against women, including obstetric violence. This issue is only being studied more recently, particularly in Latin America.

The maternal emotional experience in birth is key for postpartum outcomes, including parenting capabilities in the months after birth and women's relationships with their partners and 
babies (BEATON, 1986; BEATON 1990; BRUJIN; GOULD, 2016). If the delivery experience is emotionally traumatic, it can lead to negative consequences, especially for the mother and newborn. Violence toward a mother during this vulnerable period can have long-reaching effects, beginning with her, including her new baby and his/her development, as well as her relationship with her partner and the relationships within the whole family. Such repercussions can easily include negative effects on the health and development of the children within a family, as children depend on adults, very often their mothers, on a daily basis. An unwell mother, such as one who has suffered trauma from obstetric violence, is likely to affect the development and health of her child, which in turn compromises the future possibilities of local sustainable development.

This paper aimed to highlight voices of Colombian mothers who experienced this type of violence during pregnancy and childbirth. Keeping in mind the limitations of this study, such as the small number of participants, we argued in this paper that this kind of violence restricts these women's freedom to be agents in their own stories, consequently limiting their human development, in accordance with Amartya Sen's proposal of development, which directly relates to a person's freedom and capability to be an agent of their choices.

Health professionals around the world routinely consider themselves to be authorities and neglect the knowledge of mothers, older women and doulas or practitioners. This issue is sustained by the biomedical model, which maintains a hierarchy of knowledge and power between patients and professionals. Even among professionals, there are also power differentials that can produce institutional violence in healthcare settings. When women are not respected and are denied the freedom to actively participate in childbirth, it can result in trauma and restrict their human development. Thus, this paper intends to bring visibility to this problem, using the voices of these Colombian women to promote debate and reflection about human development without gender inequities or gender-based violence of any kind.

\section{References}

AGUiAR, J. M.; D’OLIVEIRA, A.F.P.L.; SCHRAIBER, L.B. Cad. Saúde Pública, Rio de Janeiro, 29(11):2287-2296, nov, 2013.

AGUIAR, J. M.; D'OLIVEIRA, A.F.L. Institutional violence in public maternity hospitals: the women's view. Interface Comun Saúde Educ. 2011; 15:79-92. 
BAKER, S.R.; CHOI, P.Y.L.; HENSHAW, C.A.; TREE, J. 'I Felt as though I'd been in Jail': Women's Experiences of Maternity Care during Labour, Delivery and the Immediate Postpartum. Feminism \& Psychology 15(3):315-342, 2005. https://doi.org/10.1177/0959-353505054718

BARROS, J.A.C. Pensando o processo saúde-doença: a que responde o modelo biomédico? Saúde e Sociedade. 11 (1) 67-84; 2002.

BEATON, J. Dimensions of Nurse and Patient Roles in Labour. Health Care of Women International 11: 393-408; 1990.

BEATON, M.I. Patterns of Nurse-Patient Interaction in Labour: An Analysis of Impact on Patient Perceptions of Satisfaction and Control in Childbirth. Unpublished $\mathrm{PhD}$ thesis, University of Texas, Austin, 1986.

BOHREN, M. A. et al. The Mistreatment of Women during Childbirth in Health Facilities Globally: A Mixed-Methods Systematic Review. PLoS Med.12(6):e1001847, 2015.

BOWSER, D, HILL, K. Exploring Evidence for Disrespect and Abuse in Facility-Based Childbirth: Report of a Landscape Analysis. Available from:

http://www.tractionproject.org/resources/access-skilled-care-respectful-maternal-care/exploringevidence-disrespect-and-abuse, accessed on 22/01/2018.

BRUJIN, M.; GOULD, D. How to heal a bad birth: Making sense, making peace \& moving on. Kenmore, Queensland: Birthtalk, 2016.

CAMARgo Júnior, K. R. A biomedicina. Physis Revista de Saúde Coletiva, Rio de Janeiro. v. 7, n. 1, p. 45-68, 1997.

CAMARGO JÚNIOR, K. R. Biomedicina, saber \& ciência: uma abordagem crítica. São Paulo: Hucitec, 2003.

CAMERON, D. Working with spoken discourse. London: SAGE Publications, 2001.

DAVIS-FLOYD, R. Birth as an American rite of passage. Berkeley: University of California Press, 2003.

DIAZ-TELLO, F. Invisible wounds: obstetric violence in the United States. Reprod Health Matters. 24(47):56-64, 2016. DOI: 10.1016/j.rhm.2016.04.004. Epub 2016 Jun 1.

FREEDMAN, L.P.; KRUK, M.E. Disrespect and abuse of women in childbirth: Challenging the global quality and accountability agendas. Lancet, 384(9948), e42-e44, 2014. doi: 10.1016/S01406736(14)60859-X

JENKINSON, B.; KRUSKE, S.; KILDEA, S. The experiences of women, midwives and obstetricians when women decline recommended maternity care: A feminist thematic analysis. Midwifery. 52:110, 2017. doi: 10.1016/j.midw.2017.05.006. Epub 2017 May 11. 
JORDAN, B. Authoritative knowledge and its construction. In: DAVIS-FLOYD, R.; SARGENT, C. Childbirth and Authoritative Knowledge: Cross-Cultural Perspectives. Berkeley; University of California Press, 1997. p. 55-79.

JORDAN, B.; IRWIN, S. The ultimate failure: court-ordered caesarean section. In: WHITEFORD, L.; POLAND, M. New Approaches to Human Reproduction. Boulder; Westview Press, 1989. p. 185-199.

LAZAR, M. Feminist Critical Discourse Analysis: Articulating a Feminist Discourse Praxis. Critical Discourse Studies. 4(2):141-164, 2007.

LIAMPUTTONG, P.; EZZY, D. Qualitative Research Methods. 2nd. Ed. Melbourne: Oxford, 2005.

LUPTON, D. 'Precious cargo': Foetal subjects and reproductive citizenship. Critical Public Health, 22(3), 329-340, 2012.

LUPTON, D., SCHMIED, V. Splitting bodies/selves: women's concepts of embodiment at the moment of birth. Sociology of Health \& Illness, 35(6):828-41, 2013. DOI: 10.1111/j.14679566.2012.01532

MONROY-MUNOZZ, S.A. El continuo ginecobs-tétrico: experiencias de violencia vividas por mujeres gestantes en servicios de salud en Bogotá. Masters Thesis. Universidad Nacional de Colombia, Facultad de Ciencias Humanas, Escuela de Estudios de Género, 2012.

NHMRC. National Health and Medical Research Council. Australian Research Council. Australian Vice -Chancellors' Committee National Statement on Ethical Conduct in Human Research, Canberra, 2007. Available from:

https://www.nhmrc.gov.au/_files_nhmrc/publications/attachments/e72_national_statement_may_20 15 150514_a.pdf, accessed on 22/01/2018.

RAPP, R. Commentary on "Birth in twelve cultures: papers in honor of Brigitte Jordan," a symposium at the annual meeting of the American Anthropological Association. San Francisco, December 1992.

REGIS, J.F.S. Violência e resistência: representação discursiva da assistência obstétrica no Brasil em relatos de parto e cartas à/ao obstetra [Violence and resistance: The discursive representation of obstetric care in Brasil in birth stories and letters to the obstetrician]. $\mathrm{PhD}$ thesis, Universidade de Brasília and Friedrich-Schiller-Universität Jena, 2016.

SADLER, M.; SANTOS, M.J.; RUIZ-BERDÚN, D.; ROJAS, G.L.; SKOKO, E.; GILLEN, P.; CLAUSEN, J.A. Moving beyond disrespect and abuse: addressing the structural dimensions of obstetric violence. Reprod Health Matters. 24(47):47-55, 2016. doi: 10.1016/j.rhm.2016.04.002. Epub 2016 Jun 4.

SAFFIOTI, H. I. B. Violência doméstica: questão de polícia e da sociedade. In: CORRÊA, M. (Org.). Gênero e cidadania. Campinas: Núcleo de Estudos de Gênero - Pagu, 2001. 
SAVAGE, V.; CASTRO, A. Measuring Mistreatment of Women during Childbirth: A Review of Terminology and Methodological Approaches. Reproductive Health. v.14: 138. Web. 4 Jan. 2018.

SEN, A. Desenvolvimento como liberdade. v. 11. São Paulo: Companhia das Letras, 2000.

SONEGO, M. et al. Unperceived intimate partner violence and women's health. Gac. Sanit. 2013; 27(5):440-446.

TOLTON, L. Legitimation of violence against women in Colombia: A feminist critical discourse analytic study. PhD Thesis, School of Languages and Comparative Cultural Studies, The University of Queensland, 2010.

UNITED NATIONS (UN). Transforming our world: the 2030 agenda for sustainable development. New York: United Nations, 2015.

VENEZUELA. Ley orgánica sobre el derecho de las mujeres a una vida libre de violencia. 2007. Available from: <http://www.derechos.org.ve/pw/wp-content/uploads/11.-Ley-Orgánica-sobre-elDerecho-de-las-Mujeres-a-una-Vida-Libre-de-Violencia.pdf $>$, accessed on 04/01/2018.

WORLD HEALTH ORGANIZATION (WHO). Global and regional estimates of violence against women: prevalence and health effects of intimate partner violence and non-partner sexual violence. Geneva: World Health Organization Department of Reproductive Health and Research, London School of Hygiene and Tropical Medicine, South African Medical Research Council., 2013.

WORLD HEAlth ORGANIZATION (WHO). Putting Women First: Ethical and Safety Recommendations for Research on Domestic Violence Against Women. Department of Gender and Women's Health Family and Community Health World Health Organization Geneva, Switzerland, 2001.

WORLD HEALTH ORGANIZATION (WHO). The prevention and elimination of disrespect and abuse during facility-based childbirth. Human Reproduction Program. Geneva: World Health Organization, 2015.

Artigo recebido em 13/02/2018. Aceito para publicação em 20/03/2018. 